\title{
Analisis Pengaruh Cooling Rate pada Material ASTM A36 Akibat Kebakaran Kapal Terhadap Nilai Kekuatan, Kekerasan dan Struktur Mikronya
}

Stevanus Arie Nugroho S., Totok Yulianto, dan Septia Hardi Sujiatanti

Jurusan Teknik Perkapalan, Fakultas Teknologi Kelautan, Institut Teknologi Sepuluh Nopember (ITS)

Jl. Arief Rahman Hakim, Surabaya 60111 Indonesia

e-mail: totoky@na.its.ac.id

\begin{abstract}
Abstrak-Pemadaman api pada kasus kebakaran kapal biasanya menggunakan air laut. Proses pemadaman api menyerupai perlakuan panas dengan pendinginan cepat yaitu quenching. Quenching adalah salah satu perlakuan panas pada material dengan pendinginan dalam waktu yang singkat. Penelitian ini dilakukan untuk mengetahui pengaruh laju pendinginan cepat (quench) terhadap nilai kekuatan, kekerasan serta struktur mikro dari material dengan variasi waktu quenching 30, 60 dan 90 menit serta variasi suhu $750^{\circ} \mathrm{C}, 850^{\circ} \mathrm{C}$, dan $950^{\circ} \mathrm{C}$ untuk masing-masing perlakuan quenching. Hasil dari penelitian ini didapat, material dengan perlakuan panas dan tanpa perlakuan panas memiliki nilai kuat tarik, kekerasan dan struktur yang berbeda. Didapatkan nilai kuat tarik berbanding lurus dengan nilai kekerasan namun berbanding terbalik dengan diameter butir. Nilai kuat tarik tertinggi dimiliki oleh pelat dengan perlakuan suhu $850^{\circ} \mathrm{C}$ dan quenching 30 menit dengan nilai 587.51 MPa sedangkan nilai kuat tarik terendah dimiliki oleh pelat tanpa perlakuan dengan nilai 294.817 MPa. Pelat dengan nilai kekerasan tertinggi dimiliki oleh pelat dengan perlakuan suhu $950^{\circ} \mathrm{C}$ dan quenching 30 menit dengan nilai kekerasan $167.07 \mathrm{HV}$ dan nilai kekerasan terendah dimiliki oleh pelat tanpa perlakuan dengan nilai 108.17HV. Pelat tanpa perlakuan memiliki diameter butir terbesar yaitu $85.99 \mu \mathrm{m}$ dan pelat dengan perlakuan suhu $950^{\circ} \mathrm{C}$ dan quenching 30 menit memiliki diameter besar butir 44.83 $\mu \mathrm{m}$. Tingginya kuat tarik pelat dengan perlakuan suhu $850^{\circ} \mathrm{C}$ juga disebabkan karena jumlah persentase Pearlite yang tinggi sebesar $64.56 \%$.
\end{abstract}

Kata Kunci- quenching, kuat tarik, kekerasan, struktur mikro.

\section{PENDAHULUAN}

$\mathrm{B}$ ANYAKNYA kasus kebakaran di perairan Indonesia seperti hal yang terjadi pada Landing Ship Tank (Kapal pengangkut tank) KRI Teluk Bintuni milik Angkatan Laut yang pernah terbakar pada proses pembangunannya menjadi salah satu faktor terjadinya kegagalan struktur. Hal ini disebabkan karena perubahan struktur material ketika material mengalami suhu tinggi akibat kebakaran yang langsung dipadamkan dengan air laut. Perubahan struktur ini menyebabkan material menjadi lebih getas (brittle) dan cenderung untuk mudah patah. Apabila material menjadi lebih getas, maka material itu akan memiliki nilai kekerasan yang tinggi, dan nilai deformasi plastisnya kecil atau bahkan tidak ada sama sekali.

Quenching merupakan perlakuan panas pada material dengan mempercepat penurunan suhu sampai suhu ruang pada suatu material dalam waktu yang singkat. Proses pemadaman api pada kebakaran dengan air laut memiliki kesamaan dengan quenching. Dalam bidang ilmu metalurgi, quenching dilakukan untuk mendapatkan material yang memiliki nilai kekerasan yang tinggi

\section{TINJAUAN PUSTAKA}

Penelitian ini mengacu kepada penelitian-penelitian yang telah dilakukan sebelumnya terkait permasalahan kebakaran pada kapal yang kejadiannya memiliki kesamaan dengan proses perlakuan panas pada material yaitu perlakuan quenching. Pada penelitian terkait simulasi kebakaran terhadap material ASTM A36 yang didinginkan cepat, suhu simulasi yang digunakan yaitu $750^{\circ} \mathrm{C}, 850^{\circ} \mathrm{C}$, dan $950^{\circ} \mathrm{C}$. Untuk mensimulasikannya, ASTM A36 dipanaskan di dalam oven listrik sampai suhu simulasi dan ditahan selama 120 menit dan 240 menit. Tujuannya adalah melihat pengaruh lamanya penahanan suhu terhadap nilai fracture toughness, dari material setelah diberi perlakuan quenching dengan pengujian tarik, impak, dan melihat struktur mikronya [1].

Penelitian terkait pengaruh quenching terhadap kekuatan dan sambungan plat ASTM A36 dan didapatkan bahwa penurunan kekuatan tertinggi berada pada sambungan plat ASTM A36 bersuhu $950^{\circ} \mathrm{C}$ dengan waktu 60 menit dan media air laut untuk proses quenching, yaitu sebesar 326.96 MPa untuk nilai yield strength dan 420.61 MPa untuk nilai ultimate tensile strength [2].

Di dalam studi eksperimen metode perbaikan konstruksi lambung kapal pasca kebakaran. Dari hasil penelitian tersebut didapatkan hasil pada pelat ASTM A36 yang diuji pada suhu $300^{\circ} \mathrm{C}-600^{\circ} \mathrm{C}$ nilai regangan masih pada batas yang diizinkan yaitu diatas $23 \%$, sedangkan untuk suhu antara $650^{\circ} \mathrm{C}$ sampai dengan $1000^{\circ} \mathrm{C}$ nilai regangan yang dibawah $23 \%$ dan tidak memenuhi standar ASTM, meskipun 
nilai yield strength dan ultimate tensile strength masih memenuhi standar [3].

Studi eksperimen pengaruh proses perlakuan panas terhadap kekerasan dan struktur mikro baja AISI 310 S. perlakuan yang digunakan adalah normalizing dan hardening dengan variasi temperatur $1050^{\circ} \mathrm{C}$ dan $1075^{\circ} \mathrm{C}$. Pengujian menggunakan uji kekerasan Vickers. Dari hasil penelitian yang telah dilakukan diperoleh harga kekerasan maksimal pada spesimen dengan perlakuann panas hardening pada temperatur $1075^{\circ} \mathrm{C}$ sebesar 175HV30[4].

Penelitian ini bertujuan untuk mengetahui pengaruh dari variasi laju pendinginan pada proses quenching terhadap material ASTM A36 yang dipanaskan dengan variasi suhu $750^{\circ} \mathrm{C}, 850^{\circ} \mathrm{C}$, dan $950^{\circ} \mathrm{C}$ dilihat dari besar nilai kuat tarik, kekerasan, serta struktur mikronya.

\section{METODOLOGI PENELITIAN}

\section{A. Pelaksanaan Penelitian}

Pelaksanaan penelitian didasari adanya perubahan struktur mikro pada baja ASTM A36 akibat kebakaran pada kapal sehingga terjadinya kegagalan struktur. Penelitian dimulai dengan pencarian studi literatur terkait penelitian ini, kemudian mempersiapkan material ASTM A36 dengan dimensi $300 \mathrm{~mm} \times 150 \mathrm{~mm}$ x $10 \mathrm{~mm}$ sebanyak 10 pelat yang diberi nama dengan keterangan seperti pada Tabel 1 .

Tabel 1.

Komposisi pengujian material

\begin{tabular}{cc} 
Komposisi pengujian material & \\
\hline \hline Perlakuan & $\begin{array}{c}\text { Suhu } \\
\text { Pemanasan }\end{array}$ \\
\hline Tanpa Perlakuan & - \\
Quenching 30 menit & $750^{\circ} \mathrm{C}$ \\
Quenching 60 menit & $850^{\circ} \mathrm{C}$ \\
& $950^{\circ} \mathrm{C}$ \\
& $750^{\circ} \mathrm{C}$ \\
Quenching 90 menit & $850^{\circ} \mathrm{C}$ \\
& $950^{\circ} \mathrm{C}$ \\
& $750^{\circ} \mathrm{C}$ \\
& $850^{\circ} \mathrm{C}$ \\
\hline \hline
\end{tabular}

Selanjutnya pelat dimasukkan ke dalam oven listrik dan dipanaskan hingga suhu pemanasan yang telah ditentukan. Lama holding time untuk setiap pelat adalah 120 menit untuk setiap suhunya. Setelah dipanaskan, pelat langsung dicelupkan ke dalam wadah berisi air laut untuk memulai proses quenching. Setiap pelat diberi perlakuan yang berbeda sesuai dengan Tabel 1.

Seluruh pelat dipotong menjadi spesimen untuk dilakukan pengujian kekerasan, kekuatan, dan pengamatan struktur mikro. Hasil yang diperoleh dari pengujian tersebut dilakukan analisis data dan pembahasan tentang perbandingan grafik pada setiap pelat dengan setiap pengujiannya. Sebagai langkah terakhir, dilakukan pengambilan kesimpulan dari penelitian ini.

\section{B. Bahan Penelitian}

\section{1) Tensile Test}

Di dalam proses pengujian tarik (tensile test) ini berbentuk flat tensile spesimen. Untuk penentuan ukuran spesimen uji tarik (tensile test) menggunakan standar ASTM E8-04, dapat dilihat dalam Gambar 9.[5].

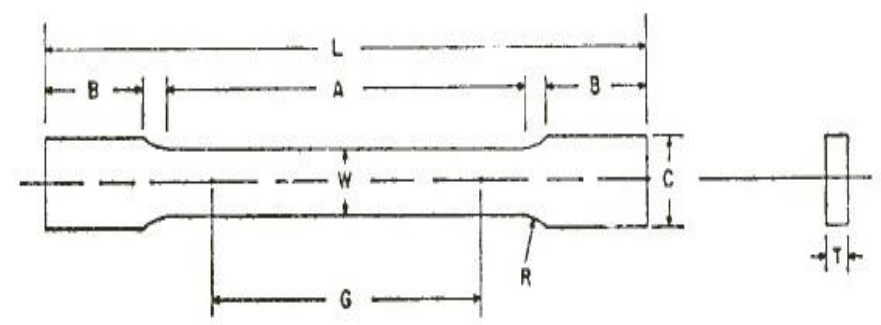

Gambar 1. Dimensi pengukuran uji tarik

Keterangan Gambar 1.

$\mathrm{G}$ : gauge length (mm)

A : length reduced section $(\mathrm{mm})$

$\mathrm{R}$ : radius of fillet $(\mathrm{mm})$

C : grip width $(\mathrm{mm})$

$\mathrm{T}$ : thickness (mm)

$\mathrm{L}$ : length (mm)

B : grip length (mm)

\section{2) Hardness Test}

Pengujian hardness ini dilakukan pada material ASTM A36 dengan menggunakan standar BKI Vol. V [6]. Dimensi ukuran specimen uji kekerasan yang digunakan adalah:

$$
\begin{array}{ll}
\text { Panjang } & : 20 \mathrm{~mm} \\
\text { lebar } & : 20 \mathrm{~mm}
\end{array}
$$

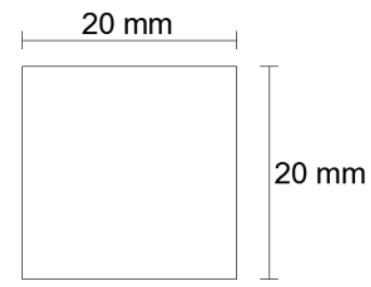

Gambar 2. Dimensi Spesimen Microhardness test

3) Analisis Struktur Mikro

Dimensi ukuran struktur mikro yang dibuat adalah:

Panjang : $20 \mathrm{~mm}$

Lebar : $20 \mathrm{~mm}$

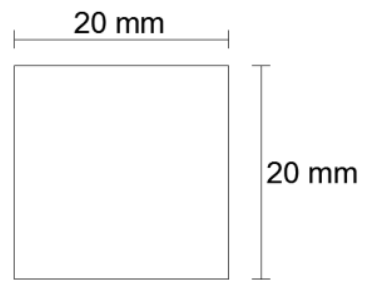

Gambar 3. Dimensi Spesimen struktur mikro

\section{4) Pengukuran Besar Butir}

Analisis dan pengukuran besar butir dilakukan dengan menggunakan metode standar pengujian untuk menentukan rata-rata ukuran besar butir. Terdapat berbagai metode yang digunakan di dalam ASTM E112, namun dalam penelitian 
ini metode yang digunakan untuk menghitung besar butir yaitu: Metode Planimetri (Jeffries Method) [7].

Rumus Empiris: $\mathrm{G}=[3,322 \log (\mathrm{Na})-2,95]$ dan $\mathrm{Na}=$ $\mathrm{f}(\mathrm{n} 1+\mathrm{n} 2 / 2)$

Dengan:

$\mathrm{G}=$ besar butir dirujuk ke tabel ASTM E112 untuk mencari nilai diameter butir

$\mathrm{Na}=$ Jumlah butir

$\mathrm{N} 1=$ Jumlah butir dalam lingkaran

$\mathrm{N} 2$ = jumlah butir yang bersinggungan dengan garis lingkaran

$\mathrm{F}=$ faktor pengali pada tabel 2 .

Tabel 2.

Faktor Pengali dalam Metode Jeffries

\begin{tabular}{cc}
\hline \hline Perbesaran & F \\
\hline 1 & 0,002 \\
25 & 0,125 \\
50 & 0,5 \\
75 & 1,125 \\
100 & 2,0 \\
200 & 8,0 \\
300 & 18,0 \\
500 & 50,0 \\
1000 & 200,0 \\
\hline \hline
\end{tabular}

Perhitungan jumlah butir menggunakan metode sebagai berikut:

1. Membagi gambar foto struktur mikro menjadi 9 kotak besar (3 kotak x 3 kotak)

2. Di setiap kotak dibagi menjadi 9x9 kotak kecil sehingga pada setiap kotak besar terdapat 100 titik

3. Pada setiap titik pada kotak besar dihitung bagian putih (Ferrite) dan gelap (Pearlite), sehingga didapatkan 100 titik Ferrite dan Pearlite pada satu kotak besar.

4. \%Ferrite (bagian terang)

5. \% Pearlite (bagian gelap)

6. Menghitung Pearlite rata-rata dan Ferrite rata-rata

\section{HASIL DAN PEMBAHASAN}

\section{A. Hasil pengujian tarik akibat pengaruh variasi quenching}

Peningkatan nilai kuat tarik pada Gambar 4 dari pelat tanpa perlakuan terhadap pelat dengan quenching 30 menit menunjukkan bahwa pengaruh pendinginan cepat dapat meningkatkan kekuatan dari material. Semakin tinggi laju pendinginan maka nilai kekuatan material semakin tinggi. Semakin tinggi nilai kuat tarik maka nilai kelenturannya akan semakin berkurang. Tingginya kuat tarik membuat karakteristik material menjadi semakin getas dan berpeluang untuk mengalami kegagalan struktur semakin tinggi apabila terkena beban yang melebihi kemampuannya.

Pada perlakuan $950^{\circ} \mathrm{C}$, pelat dengan quenching 30 menit memiliki nilai ultimate tensile strength tertinggi namun yield strength terendah, apabila ditinjau dari besar butir dan struktur mikronya komponen struktur mikro yang terdapat dalam pelat tersebut memiliki besar butir yang cenderung lebih kecil dibanding dengan yang lain sehingga stress pada material tersebut lebih kecil.

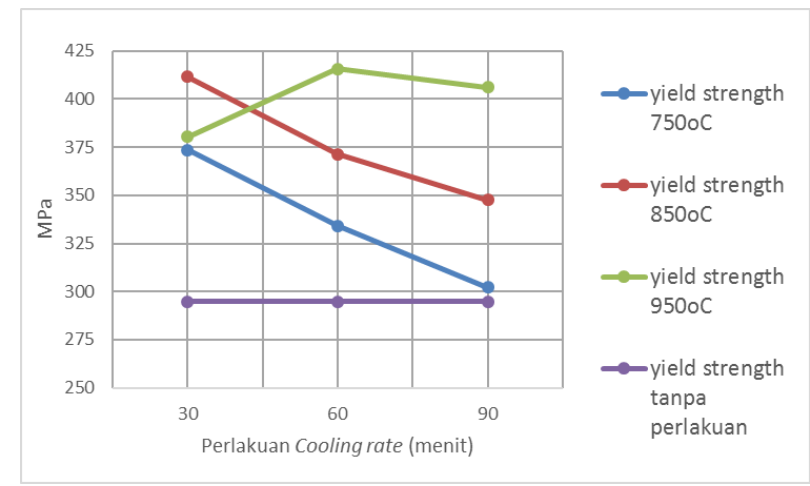

Gambar 4. Grafik hasil seluruh nilai yield strength pengaruh variasi suhu dan kecepatan quenching

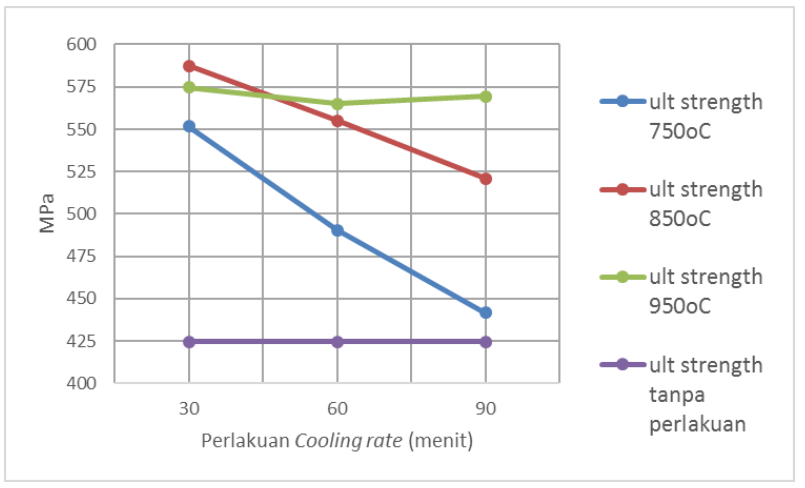

Gambar 5. Grafik hasil seluruh nilai ultimate strength pengaruh variasi suhu dan kecepatan quenching

\section{B. Hasil pengujian tarik akibat pengaruh Suhu}

Pengaruh suhu pada hasil pengujian tarik menunjukkan bahwa semakin tinggi suhu maka nilai yield strength dan ultimate strength dengan variasi waktu quenching yang tetap memiliki nilai yang lebih tinggi. Namun terdapat sedikit perbedaan pada kasus ini, yakni nilai yield strength tertinggi pada proses quenching 30 menit dimiliki oleh pelat dengan suhu $850^{\circ} \mathrm{C}$, sedangkan untuk yield strength $950^{\circ} \mathrm{C}$ nilainya mendekati suhu $750^{\circ} \mathrm{C}$.

Nilai ultimate strength yang dimiliki oleh pelat dengan perlakuan quenching 30 menit memiliki nilai yang cukup tinggi dengan selisih yang tidak terlalu jauh, hal ini menunjukkan bahwa dibandingkan dengna kecepatan pendinginan yang lain, semakin tinggi laju pendinginan maka material akan semakin kuat. Selisih yang tidak terlalu besar bahwa perbandingan suhu yang digunakan tidak terlalu nampak terlihat dalam pengujian tarik, hal ini terlihat dari selisih antara pelat dengan perlakuan dan tanpa perlakuan quenching.

\section{Hasil pengujian kekerasan akibat pengaruh quenching}

Bedasarkan hasil pengujian yang terlihat pada Gambar 6, nilai hardness tertinggi dimiliki oleh pelat dengan perlakuan 
suhu $950^{\circ} \mathrm{C}$ pada setiap perlakuan kecepatan pendinginan yang berbeda, sedangkan nilai terendah dimiliki oleh pelat tanpa perlakuan. Nilai kekerasan dari sebuah material menunjukkan komposisi struktur mikro yang terbentuk. Pendinginan yang cepat atau ekstrim menyebabkan munculnya pearlite dalam jumlah yang banyak pada pelat.

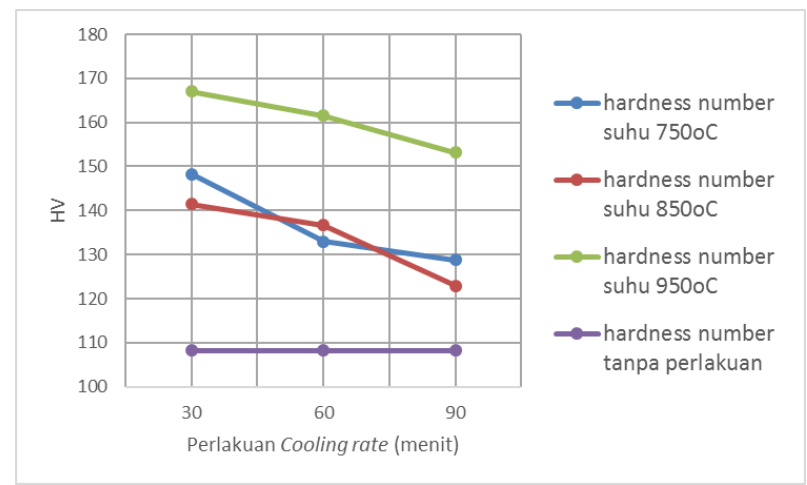

Gambar 6. Grafik hasil seluruh nilai hardness test pengaruh variasi suhu dan kecepatan quenching

Penurunan nilai kekerasan juga dipengaruhi oleh kecepatan pendinginan dari pelat tersebut. Pada pelat dengan kecepatan pendinginan 30 menit, memiliki nilai yang lebih tinggi dibandingkan dengan nilai 60 menit dan 90 menit.

\section{Hasil Pengujian Kekerasan Akibat Pengaruh Suhu}

Hasil dari pengujian akibat pengaruh suhu mengacu pada Gambar 6 dengan perbandingan waktu quenching selama 30 menit, didapatkan bahwa nilai $\mathrm{HV}$ tertinggi dimiliki oleh pelat perlakuan $950^{\circ} \mathrm{C}$ sebesar 167.07 sedangkan dibandingkan dengan kedua pelat dengan perlakuan yang sama, nilai dari nilai terendah dimiliki oleh pelat perlakuan suhu $850^{\circ} \mathrm{C}$ dengan nilai 141.47 .

Dari hasil pengujian kekerasan dengan perbandingan waktu quenching selama 60 menit, didapatkan bahwa nilai $\mathrm{HV}$ tertinggi dimiliki oleh pelat perlakuan $950^{\circ} \mathrm{C}$ sebesar 161.53 sedangkan dibandingkan dengan kedua pelat dengan perlakuan yang sama, nilai dari nilai terendah dimiliki oleh pelat perlakuan suhu $750^{\circ} \mathrm{C}$ dengan nilai 132.93 .

Dari hasil pengujian kekerasan dengan perbandingan waktu quenching selama 90 menit, pada Gambar 6 didapatkan bahwa nilai $\mathrm{HV}$ tertinggi dimiliki oleh pelat perlakuan $950^{\circ} \mathrm{C}$ sebesar 153.13 sedangkan dibandingkan dengan kedua pelat dengan perlakuan yang sama, nilai dari nilai terendah dimiliki oleh pelat perlakuan suhu $850^{\circ} \mathrm{C}$ dengan nilai 122.97 .

\section{E. Hasil Perhitungan Besar Butir}

Pada perhitungan diameter butir pada Gambar 7 didapatkan bahwa diameter terbesar adalah pelat tanpa perlakuan sedangkan diameter yang terkecil adalah pelat dengan perlakuan quenching 30 menit suhu $950^{\circ} \mathrm{C}$. hal ini menunjukkan bahwa laju pendinginan mempengaruhi diameter butir pada material. Semakin lama durasi quenching yang diterapkan maka membuat butir material kembali membesar karena pendinginan berjalan lambat setelah suhu pada medium dengan suhu pada material sudah setimbang (pendinginan berjalan secara alami akibat pengaruh udara terhadap medium air laut).

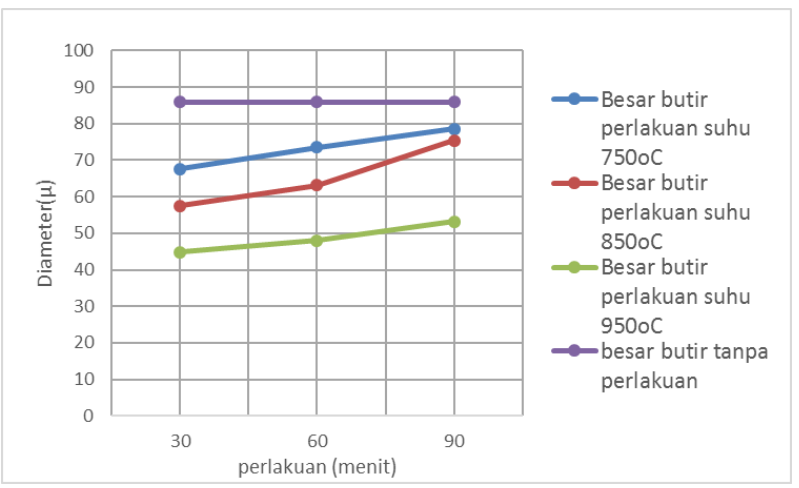

Gambar 7. Grafik hasil seluruh ukuran besar butir

Material yang memiliki ukuran butir yang semakin kecil maka nilai kekuatan dan kekerasannya akan lebih tinggi dibandingkan dengan yang memiliki ukuran butir yang lebih besar karena sebelumnya memiliki batas butir yang lebih besar untuk menahan gerak dislokasi.

\section{KESIMPULAN}

1. Nilai kuat tarik juga dipengaruhi oleh suhu dan laju pendinginan yang dilakukan kepada pelat, semakin tinggi suhu dan laju pendinginannya maka nilai kuat tarik akan semakin tinggi, begitupun dengan ukuran butir yang semakin mengecil serta nilai kekerasan yang tinggi.

2. Variasi waktu yang sama dengan suhu yang rendah atau tanpa perlakuan sama sekali, maka nilai kuat tarik akan semakin kecil, ukuran butir semakin besar dan nilai kekerasan akan semakin rendah juga, seperti yang ditunjukkan pada pelat tanpa perlakuan memiliki nilai kuat tarik yang terendah yaitu $424.49 \mathrm{MPa}$ dan nilai kekerasan yang terendah sebesar 108.167 HV yang memiliki ukuran butir terbesar dengan diameter 85.9 $\mu \mathrm{m}$ namun pada pelat dengan perlakuan quenching 30 menit dan suhu $950^{\circ} \mathrm{C}$ memiliki ukuran diameter butir terkecil yaitu $44.8 \mu \mathrm{m}$ dan nilai kekerasan tertinggi sebesar 167.07 HV

3. Pelat perlakuan quenching 30 menit dan suhu $850^{\circ} \mathrm{C}$ memiliki kuat tarik terbesar dengan nilai $587.51 \mathrm{MPa}$. Hal ini juga disebabkan karena lebih tinggi komposisi Pearlite yang terbentuk pada pelat perlakuan quenching 30 menit dan suhu $850^{\circ} \mathrm{C}$ dibandingkan dengan pelat perlakuan quenching 30 menit suhu $950^{\circ} \mathrm{C}$ dengan jumlah masing-masing $64.56 \%$ dan $63.4 \%$.

4. Pengujian ini dapat menjadi referensi untuk galangan kapal maupun pemilik kapal untuk mengambil keputusan dalam reparasi kapal yang mengalami kebakaran. 


\section{DAFTAR PUSTAKA}

[1] Limbong,S. (2015). Studi. Analisis Material ASTM A36 Akibat Pengaruh Suhu dan Proses Quenching Terhadap Nilai Ketangguhannya. Surabaya: Jurusan Teknik Perkapalan Fakutlas Teknologi Kelautan Institut Teknologi Sepuluh Nopember.

[2] Donald. (2014). Undergraduate Thesis. Studi Eksperimen Pengaruh Quenching terhadap Kekuatan dan Struktur Mikro pada Sambungan Plat ASTM A36. Surabaya: Jurusan Teknik kelautan Fakultas Teknologi Kelautan Institut Teknologi Sepuluh Nopember.

[3] Baihaqi, I. (2004). Tesis. Studi Metode Perbaikan Konstruksi Lambung Kapal Pasca Kebakaran. Surabaya: Jurusan Teknik Produksi dan Material Kelautan Fakultas Teknologi Kelautan Institut Teknologi Sepuluh Nopember.

[4] Rochiem, R. (2009). Studi. Pengaruh Proses Perlakuan Panas Terhadap Kekerasan dan Struktur Mikro Baja AISI 310 S. Surabaya: Jurusan teknik material dan metalurgi Fakultas Teknologi Industri Institut Teknologi Sepuluh Nopember.

[5] ASTM.E8. (2004) Standard Test Methods for Testing of Metallic Materials. West Conshohocken: American Society for Testing and Materials.

[6] Biro Klasifikasi Indonesia Volume V, Sec. 2-G.2 . (2012). Rules for Materials. Jakarta: Biro Klasifikasi Indonesia.

[7] ASTM.E112. (2004). Standard Test Methods for Determaining Average Grain Size. West Conshohocken: American Society for Testing and Materials. 